\title{
Community Conserved Traditional Cuisine Arts in Borena Zone, Ethiopia
}

\author{
Girum Faris, Guta Waktole, Rahel Tilahun \\ Access and Benefit Sharing Directorate, Ethiopian Biodiversity Institute, Addis Ababa, Ethiopia
}

\section{Email address:}

girumf@gmail.com (G. Faris)

\section{To cite this article:}

Girum Faris, Guta Waktole, Rahel Tilahun. Community Conserved Traditional Cuisine Arts in Borena Zone, Ethiopia. Science Research. Vol. 9, No. 5, 2021, pp. 75-79. doi: 10.11648/j.sr.20210905.11

Received: September 9, 2021; Accepted: September 29, 2021; Published: October 15, 2021

\begin{abstract}
Traditional knowledge (TK) refers to knowledge, innovations, and practices of local communities in globe. Documentation of TK helps to identify local community with whom benefit of commercialization of such knowledge is to be shared. This study aimed to document traditional knowledge associated with food and beverage preparation in Borena Zone of Oromia Region. The data was collected using semi-structured questionnaires, interviews, and focus group discussions. Informants were recommended by district's Culture and Tourism offices. Preparation method, ingredients, mode of preparation, current status, and purpose of preparation were the focus point of data collection. Data was analyzed by SPSS version 21. A total of 64 individuals ( 25 men and 39 women); aged 17 to 78 with mean age of $40.00 \pm 15.44$ years were recruited. The minimum, maximum, and average years they lived in the study area were 17, 78, and $40.00 \pm 15.44$, respectively. Findings revealed that a total of eleven traditional foods and drinks were listed by respondents: Yabelo nine (six traditional foods and three traditional drinks); Dire nine (six traditional foods and three traditional drinks); and Arero six (four traditional foods and two traditional drinks). Salting, drying, boiling, toasting, frying, baking, cooking, and fermentation are the major practices that were used by the community to prepare their local foods or drinks. Informants prepare the foods/beverages customarily during public holidays such as memorial days and birth day; and occasionally for wedding ceremony, funeral, visiting respected relatives, and for respected invitee. Economic problems, urbanization, and benefiting modernization were claimed by informants that these are determinant factors to prepare traditional foods/beverages frequently at home. To conclude, there is great gap in using traditional knowledge associate with foods and beverages preparation in Ethiopia. There should be special emphasis to optimize preparation procedures through modern biotechnology and promote for commercialization access for modern companies to share benefits arising from the utilization.
\end{abstract}

Keywords: Traditional Knowledge, Foods, Beverages, Bioprospecting

\section{Introduction}

Traditional knowledge can be found in a wide variety of contexts, including: agricultural, scientific, technical, ecological and medicinal knowledge as well as biodiversity-related knowledge. It has great role in many research fields including drug development, rural engineering, resource management, and in bio-prospecting, and researching this field is vital for scientific community, conservation of the knowledge and protection from unethical patents [12]. It plays an important role in the global economy. Traditional peoples and communities are responsible for the discovery, development, and preservation of a tremendous range of medicinal plants, health-giving herbal formulations, and agricultural and forest products that are traded internationally and generate considerable economic value [5]. There is strong linkage between sustainable development and traditional knowledge; and it contributes to the attainment of sustainable economic development of a country [10].

Traditional foods or beverages are natural diets or drinks which nourished our ancestors throughout the evolutionary history of human particularly in the prehistory of the industrialization of food or beverage. In Ethiopia, the history of traditional foods or beverages is dating to the early of crop domestication and agriculture innovation, and it is linked to celebrations such as holidays, festivals, social gatherings, 
funeral, to honor guests, and special occasions [1,8].

The indigenous knowledge systems are a significant resource which would contribute to the increased efficiency, effectiveness and sustainability in environmental conservation among rural communities of developing countries in particular. They form the basis for community-level decision making in areas pertaining to food security, human and animal health, education and more important in natural resource management [2].

It has also an input into modem industries such as pharmaceuticals, botanical medicines, cosmetics and toiletries, agriculture, and biological pesticides. In most cases, corporations that can harness advanced scientific, technological, and marketing capabilities capture virtually all of the value added [5]. This survey aimed to document typical traditional Cuisine Arts of Borena Region to fulfill the following specific objectives, (1) To list traditional practices used to prepare foods and beverages (2), To document traditional assay (procedures) to prepare food and beverage and (3) To document types of traditional foods or beverages prepared.

Many traditional beverages are prepared by Ethiopians at household level in different parts of the country. Most of these beverages are fermented alcoholic drinks and prepared from plant origins to celebrate holydays and to honor a guest, at festivals and social gatherings, at burial ceremonies and settling disputes. Among fermented foods, alcoholic beverages have been widely consumed since prehistoric times by people around the world. Fermented products can play an important role, contributing to the livelihoods of rural and perturbing dwellers [7, 9].

\section{Material and Methods}

\subsection{Study Area}

The study was conducted in three districts of Borena Zone of Oromia Region. Borena Zone has 9 districts namely Yabelo, Arero, Moyale, Dire, Teltele, Abaya, Dugida Dawa, Miyu, and Gelana [4]. From these Yabelo, Dire, and Arero districts were purposively selected by Borena Zone Culture and Tourism Administrative office based on their dependence on traditional foods and beverages.

\subsection{Data Collection}

The data were collected using semi-structured questionnaires, interviews and focus group discussions using local dialects. The questions were prepared in English and then translated into local language. The whole processes were administered with the help of interpreters who were educated and understood the questionnaires as well as the objectives of the study.

Local administrators, Kebele leaders, and/or knowledgeable elders were invited to propose appropriate informants based on the preset inclusion criteria. The informants those recommended by these community segments were invited to participate in the study. The inclusion criteria were traditional food and beverage preparation experience, skill, knowledge, and practice. The selected informants were recruited with the help of corresponding district's Culture and Tourism and Administrative Office.

For each traditional food preparation method, the informants were asked to explain methods/procedures of preparation, components/ingredients, type of traditional food /beverage, local name of the food/beverage, and mode of preparation. The information regarding the preparation of a particular traditional food or beverage using a particular procedure was treated as an individual report. During data collection pictures and/or video of the traditional food or beverage was taken.

\subsection{Data Analysis}

The data was summarized using descriptive statistics and presented by percentages, frequency distribution, tables, charts and graphs. P-values less than 0.05 were considered statistically significant and all the analysis were done using SPSS version 21, software.

\section{Results}

\subsection{Socio-demographic Characteristics}

The age of the respondents varied between minimum age of 17 years and maximum age of 78 years. The mean age of the respondents was $40.00 \pm 15.44$ years. The minimum years the respondents lived in the study area is 17 years and the maximum is 78 year and the mean was $40.00 \pm 15.44$ years. Figure 1 shows the relationship between the age of the respondents and the number of years they lived in the study area. All respondents were Oromo ethnic, Pastoralist, and married.

Table 1. Socio-demographic characteristics of respondents.

\begin{tabular}{|c|c|c|c|c|c|c|c|}
\hline & & Yabelo & Dire & Arero & Total & Frequency & Percent \\
\hline \multirow{2}{*}{ Gender } & Female & 14 & 19 & 6 & 39 & 0.609375 & 61 \\
\hline & Male & 12 & 6 & 7 & 25 & 0.390625 & 39 \\
\hline \multirow{2}{*}{ Education } & Litrate & 11 & 3 & 1 & 15 & 0.234375 & 23 \\
\hline & Illiterate & 15 & 22 & 12 & 49 & 0.765625 & 77 \\
\hline \multirow{3}{*}{ Religion } & Wakefata & 19 & 21 & 13 & 53 & 0.828125 & 83 \\
\hline & Muslim & 3 & 2 & 0 & 5 & 0.078125 & 8 \\
\hline & Protestant & 4 & 2 & 0 & 6 & 0.09375 & 9 \\
\hline
\end{tabular}




\subsection{Inclusion and Exclusion Criteria Evaluation}

All respondents were born in the study area. Their experiences on traditional food and beverage preparation were well recognized by the district's Cultural and Tourism
Administration Office. The number of years the respondents lived in the study area was similar to their age. All respondents were born and spent their whole age in the study area.

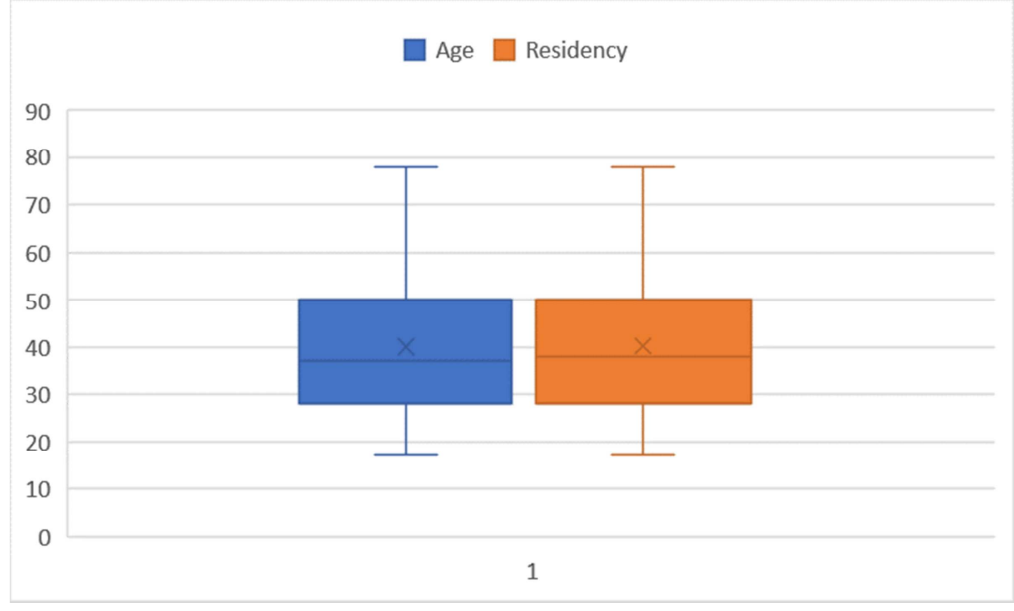

Figure 1. Mean plot of study participants' age and number of years they lived in the area.

\subsection{Traditional Foods and Beverages Prepared by the Local Community}

Table 2. Traditional foods and drinks prepared by the local community.

\begin{tabular}{lllll}
\hline \multirow{2}{*}{ Traditional foods/beverages } & \multicolumn{3}{l}{ Districts } & \\
\cline { 2 - 5 } & Buna Kala & present & present & present \\
& Koche & present & present & present \\
& Guba & & present & present \\
$\begin{array}{l}\text { Local name of the } \\
\text { traditional food }\end{array}$ & Waddi & present & present & \\
& Boka & & present & present \\
& Qamani & present & present & \\
& Fon Dhoban/affeli & present & & \\
Watala & present & & \\
Local name of the & Mihi & present & present & \\
traditional & Ititu & present & present & present \\
beverages & Qamana & present & present & present \\
\hline
\end{tabular}

Generally, eight traditional foods and three traditional drinks were listed by study participants from three districts of Borena Zone: Yabelo nine (six traditional foods and three traditional drinks); Dire neine (six traditional foods and three traditional drinks); and Arero six (four traditional foods and two traditional drinks). Table 2 presents the list of traditional foods and beverages mentioned by respondents in each district.

\subsection{Traditional Foods/Beverages Processing Practices}

Totally, 11 unique traditional food and beverage processing methods were recorded based on individual person interview and group discussion. These processes were practiced by respondent for the purpose of celebration and occasional cases. Most traditional foods or beverages were prepared regularly following yearly coming ceremonial days like religious holidays. However, the practices to prepare some foods and beverages were decreasing due to economic problems, urbanization, and introduction different religion in the community. As informed by informant during group discussion preparation of some traditional foods are challenging because of the amount of money needed based on the current market. Table 3 presents list of food processing and their related factors.

Table 3. Practices of traditional food/beverage preparation by the local community.

\begin{tabular}{|c|c|c|c|c|c|c|}
\hline & & $\begin{array}{l}\text { Purpose of } \\
\text { preparation }\end{array}$ & $\begin{array}{l}\text { Responsible } \\
\text { person to prepare }\end{array}$ & Status & Affordability & $\begin{array}{l}\text { Eligible group to } \\
\text { eat or drink }\end{array}$ \\
\hline \multirow{7}{*}{$\begin{array}{l}\text { Local name of } \\
\text { the traditional } \\
\text { food }\end{array}$} & Buna Kala & Customary & Female & Constant & Affordable & Eligible to all \\
\hline & Koche & Customary & Female & Constant & Affordable & Eligible to all \\
\hline & Guba & Occasional & Male & Constant & Affordable & Eligible to all \\
\hline & Waddi & Customary & Female & Constant & Affordable & Eligible to all \\
\hline & Boka & Ceremonial & Female & Constant & Affordable & Eligible to all \\
\hline & Qamani & Ceremonial & Female & Constant & Affordable & Eligible to all \\
\hline & Watala & Ceremonial & Male & Constant & No & Eligible to all \\
\hline \multirow{3}{*}{$\begin{array}{l}\text { Local name of } \\
\text { the traditional } \\
\text { beverages }\end{array}$} & Mihi & Ceremonial & Female & Constant & Affordable & Eligible to all \\
\hline & Ititu & Ceremonial & Female & Constant & Affordable & Adults \\
\hline & Qamani & Occasional & Female & Constant & Affordable & Adults \\
\hline
\end{tabular}




\section{Discussions}

In this study, the gender, age, ethnicity, profession, religions and other socioeconomic demographic factors that would affect individual knowledge were controlled using inclusion and exclusion criteria [3]. The average age of the respondents was 40 years: and it was similar to the number of years they lived in the study area. This keeps the assumption that the respondents might have better acquisition, observation, collection and practices of the sociocultural experiences of the local community in the study area considering that growing experience comes with age [14]. The number of females involved in the study was purposively maximized because, in Ethiopian culture, females are responsible to prepare foods and/or beverages at home and it is unusual to see the direct involvement of Ethiopian men to prepare traditional foods and/or beverages.

Ethiopia is a multiethnic country having heterogeneous cultural diversity which is manifested from using various techniques to prepare traditional foods and beverages [11]. In this study, 8 traditional foods (Buna Kala, Koche, Guba, Waddi, Boka, Qamani, Fon Dhoban/affeli, and Watala) and 3 traditional drinks (Mihi, Ititu, and Qamani) were listed based on the information obtained from respondents. The listed foods/beverages are specific to the local community and they are highly linked to their cultural values. They are prepared by the local community for the purpose of Ceremonial (e.g. religious festival) and occasional cases (e.g. to honor guests). According to other previous similar studies, beside the slight difference in recipes, some of the above listed traditional beverages are widely produced and consumed in different part of the country.

The eleven unique traditional food and drinks processing methods were recorded based on individual person interview and group discussion. The preparation of traditional foods and beverages is a household art. The process typically includes salting and drying, boiling, roasting, frying, baking, cooking, fermenting or various combinations of these. These processes were practiced by respondents regularly. Throughout history, traditional food/beverage preparation and consumption is at the heart of celebration and identity of the community [6]. Such cooking practices may give a special identity to those who gather together to enjoy traditional foods as a community, creating unique atmosphere of well-being, familiarity, and togetherness, belongingness, and comradeship [6]. This was also what we understood from respondents' feelings during group discussion to collect data. This makes possible the exchange of experiences and beliefs that is the foundation of any cohesive community.

However, the practices to prepare some foods and beverages were decreasing due to pressures from economic problem, urbanization, benefiting modernization, and introduction different religions in the community. As informed by respondents during group discussion, preparation of some traditional foods and beverages like Guba, Koche, Watala, and Boka were challenging because of the amount of money needed to prepare based on the current market. These problems may lead to loss of traditional practices in cultural landscapes [13]. Informants claimed that cost is the major determinant factor to frequently prepare traditional food/beverage at home neglecting the popularity of the food or beverage in the community. For instance, Guba and watala are the most popular foods (ranked as first) in Arero and Yabello districts but because of their cost the minimum frequency of preparation per year is very limited. This might have been causing community classes based on their incomes.

\section{Conclusion}

In conclusion, eleven traditional foods were identified that are unique and connected to culture and emotions of the people living in the study. Beside this certain food processing household arts such as salting and drying, boiling, roasting, frying, baking, cooking, fermenting or various combinations of these in the community were also identified. In contrast, the tendency to maintain traditional food processing arts is on the way of declining due to attraction to modern way of life styles.

Based on the findings of this study all concerned bodies should pay attention in maintaining the traditional arts of food preparation and its promotion of these arts to the rest of the world so as to get accessed by bioprospecting companies.

\section{Acknowledgements}

We acknowledge our study respondents for sharing us their knowledge. We also thankful to District Culture and Tourism Office experts for their facilitation and guidance during the study period. Finally, we are grateful to Ethiopian Biodiversity Institute (EBI) for its financial support for fieldwork activities.

\section{References}

[1] Anteneh T, Tetemke M, Mogessie A (2011). Antagonism of lactic acid bacteria against foodborne pathogens during fermentation and storage of borde and shamita, traditional Ethiopian fermented beverages. Int. Food Res. J. 18: 1189-1194.

[2] Ayaa D., Waswa F. (2016): Role of indigenous knowledge systems in the conservation of the bio-physical environment among the Teso community in Busia County-Kenya. Afr J Env Sc Technol, 10 (12): 467-475.

[3] Augustine A. Ayantunde \& Mirjam Briejer (2008): Botanical Knowledge and its Differentiation by Age, Gender and Ethnicity in Southwestern Niger. Hum Ecol, 36: 881-889.

[4] Central Statistics Authority of Ethiopia (2013). Population Projection of Ethiopia for all Regions at Woreda Level from 2014-2017, Federal Democratic Republic of Ethiopia Central Statistical Authority, Addis Ababa, Ethiopia.

[5] Dutfield G. (2001). TRIPS-Related Aspects of Traditional Knowledge. Case W. Res. J. Int'l L., 33 (2): 233-275. 
[6] Felix M A L. (2016): Regulating Safety of Traditional and Ethnic Foods. Elsevier, Academic Press, Page xvii, ISBN 9780128006054 .

[7] Gadaga TH, Mutukumira AN, Narvhus JA, Feresu SB (1999). A review of traditional fermented foods and beverages of Zimbabwe. Int. J. Food Microbiol. 53: 1-11.

[8] Hall CM, Sharples L (2008). Food and Wine Festivals and Events Around the World: Development, Management and Markets.

[9] Jeyaram K, Singh TA, Romi W, Devi AR, Singh WM (2009). Traditional fermented foods of Manipur. Knowledge Creation Diffusion Utilization. 8: 115-121.

[10] Kwa E. L. (2005): The Role of Traditional Knowledge in Achieving Sustainable Economic Development, For the "Sustainable Economic Development of Indigenous Communities in New Zealand and the Wider Pacific Region" Conference (20-21 June 2005, Rotorua).
[11] Mogessie Ashenafi (2002): The microbiology of Ethiopian foods and beverages: A review. SINET: Ethiop J Sci 25 (1): 97-140.

[12] Pathak M., Bharati K. A. (2018). Growing visibility and impact of Indian Journal of Traditional knowledge. Indian journal of traditional knowledge 17 (3): 407-413.

[13] Potdar K., Namrata N., Sami A. (2018): Nature, Culture and Humans: Patterns and Effects of Urbanization in Lesser Himalayan Mountainous Historic Urban Landscape of Chamba, India. Journal of Heritage Management, 2 (2): 169-188.

[14] Staudinger U. M. (1999): Older and Wiser? Integrating Results on the Relationship between Age and Wisdom-related Performance. International Journal of Behavioral Development, 23 (3): 641-664. 